\title{
ミニシンポジウム IV
}

\section{脳疾患と排尿障害}

\author{
司会 安田 耕作（千葉大）
}

目的：高齢化社会が進むにつれて脳疾患による排尿 障害が増加している。しかしこの分野での研究成果は 極めて少なく，いまだ治療扔よび予防の参考となるも のは殆どないと言っても過言ではない. 総会会長より 若い研究者に，この未開の分野を大きく切り開いて欲 しいとので要望がありましたので，本ミニシンポジウ ムに於いて大胆に脳疾患による排尿障害研究の出発点 を提案したいと思う。

これまでの報告とそれらの問題点：脳疾患による排 尿障害の報告は，(1)疾患部位別，(2)時期別，(3)動物実 験，(4)治燎に分けられる.この内(4)治療については時 間の関係で将来の検討事項として省くことにする. (1) についての問題点は症状のみで報告されているものが 多く，ごく最近のものでも膀胱内圧測定のみがなされ ていることである．尿疾禁あるいは尿閉という表現が 使用されているが前者の場合切迫性, 反射性あるいは 溢流性なのかがはっきりしない。後者の場合には排尿 筋無反射なのか排尿筋括約筋協調不全なのかが全く論 じられない(当然排尿筋内括約筋協調不全も)。今回の 発表では各演者とも総合的な尿流動態検查成績に基づ いた報告をしていただく. (2)時期別の検討をした報告 は極めて少ない，脊随損傷と同じょうに急性期，回復 期抒よび慢性期の順に特徵的な病変を示すかどうかが 問題である。(3)動物実験で排尿生理の研究は沢山なさ れている。しかしこれらで得られた成績を人の排尿生 理の解釈にどのように役立てるかの検討が必要であ る.

各演者の発表成績：(1)部位別. 大脳皮質疾患での排 尿症状は $47 \%$ ( 1 力月以上持続 $32 \%$ ), 尿流動態検査で は無抑制収縮が78\%，排尿筋括約協調不全および括約 筋無抑制弛緩がそれぞれ約 $10 \%$ に認められた。部位と しては前頭葉内側にまた刺激症状と排尿筋過活動が多 くみられた。 大脳基底核疾患ではパーキンソン病を代 表としてあげると排㽷症状は63.4\%（閉塞症状 $55 \%$, 刺激症状 $60 \%$ )，尿流動態検查では無抑制収縮が $50 \%$, 排尿時膀胱機能で低活動 $33 \%$ が認められた。脳幹部疾 患での排㽷症状は $27 \%$, 尿流動態検査では無抑制収縮
は $64 \%$, 低活動 $21 \%$, 排尿筋括約筋協調不全 $29 \%$ を認 めた。(3)についての問題点は例えば橋排尿中枢の電気 刺激や薬物注入による実験結果が人の排尿生理を理解 するのにどのように役立つか，種差はどうなのかある いは知覚に関する実験はどうするのかなどである。こ れまでの成績では橋排尿中枢及び大脳皮質には排尿促 進と抑制する部位が判明している。今回の報告は以下 のようなものであった. 大脳切除実験では, 前方 $1 / 3$ 内 側部切除では排尿閾值膀胱容量が増加したが残尿はな く最大膀胱収縮圧にも変化はなかった。その他の部位 の切除では変化はなかった，橋排尿中枢に神経系標識 物質 (HRP) を注入し入出力部位を検索すると大脳皮 質から仙髄に至る多くの領域と入出力関係があった.

結語: 大脳皮質では排尿反射抑制の低下による蓄尿 障害が主体である。前頭葉内側病変では排尿反射の低 下による排出障害がごくまれに認められるのでこれら の部位が大脳排尿中枢であろう. 大脳基底核の作用は 排尿反射を主に抑制, 従に促進すると考えられる。脳 幹部疾患では排尿反射の光進ばかりでなく排尿反射の 低下や排尿筋括約筋協調不全による排出障害が排尿障 害の比率を増してくる. 動物実験から以下の事がいえ る。大脳皮質は排尿反射そのものに影響を与えないが 排尿開始時点の決定に関与している。橋排尿中枢 (LCa) は単なるスイッチ回路ではなく排尿中も膀胱収 縮を促進し LCa に促進系入力が増加すると無抑制収 縮となる．排尿抑制の中枢（LSCやPo0）は蓄尿に関 与し，一旦排尿が始まるとそれらの影響はないことが 示された。

大脳疾患と排尿障害の今後の研究 : 本シンポジウム より今後の展望として以下の三項目をあげる.1）責任 病巣と排尿障害の関係を明らかにしたい,2）これまで の研究法即ち問㟝と膀脱内圧測定だけでなく, 外尿道 括約筋や内尿道括約筋機能を含めて検討したい, 3）脳 疾患類似の排尿障害の動物モデルを作成し薬物効果を 検討したい.

動物実験から：菅谷公男（秋田大）目的：動物実 験では脳内の多くの領域に電気刺激で排尿促進や抑制 
を誘発できる部位が比較的隣接して存在する.しかし， 橋以下の神経系さえあれば排尿閾値膀胱容量は小さい ものの残尿のない排尿が起こる. 橋には排尿反射に必 須の橋排尿中枢があり，その腹外側と内側部には排尿 抑制に働く部位が存在する。今回はネコとラットの実 験から橋のこれら 3 つの部位の排㽷と蓄尿における機 能をより上位の中枢神経系との関係から検討した。

方法：上丘前緑で除脳したネコを用い，橋吻側部に おいて電気刺激法, 細胞外電位記録法, 化学的刺激法 と膀胱内圧測定及び外尿道括約筋筋電図を組み合わせ た実験から橋の排尿関連部位の生理的機能について検 討した. 八ロセン麻酔下のネコを用いてこれら 3 力所 の排尿関連部位にそれぞれ神経標識物質を微量注入し て脳内の入出力部位を検討した。 また, 無麻酔拘束下 のラットを用いて大脳皮質部分除脳の前後で膀胱内圧 測定を行い，排尿における大脳皮質の機能について㭘 討した。

結果：除脳ネコを用いて橋吻側背外側部を電気刺激 すると青斑核アルファ (LCa)の位置で反射性排尿と同 様な膀胱収縮と外尿道括約筋の弛緩を伴った排尿が誘 発された.この部位とその近接で排尿時の細胞外電位 を記録すると，排尿時に活動が増強する細胞と蓄尿時 に活動が増強する細胞が混在していた。しかし, 氽随 L10電気刺激に一定潜時で応答する細胞, つまり L1 以下に軸索を投射する細胞に限ると排尿時に活動する 細胞は LCaに, 蓄尿時に活動する細胞は青斑下核 (LSC) と吻側橋網様核 (Po0) に限局していた。また, 排尿時に活動する細胞は膀胱収縮の開始時に活動が増 強するタイプと膀胱収縮中活動が持続するタイプが あった。そこで，LSCを持続電気刺激しながら膀胱内 に注入すると膀胱収縮が抑制され，外尿道括約筋活動 が増強した．Po0の電気刺激では膀胱収縮が抑制され る傾向にあったが, カルバコールを局注すると膀胱収 縮と外尿道括約筋の両方を完全に抑制し, 溢流性尿失 禁の状態になった。八ロセン麻酔下のネコのこれら 3 力所にそれぞれ神経標識物質の HRP を注入すると神 経線維の投射経路はそれぞれ異なるものの，3 力所と もこれまで電気刺激実験で排尿促進や抑制部位として 報告されている大脳皮質から仙髄までの多くの部位と 入出力関係にあった。次に 3 力所の橋排水関連部位が 入力すると考えられる各種神経伝達物質を想定し，除 脳ネコを用いてそれぞれの部位に神経伝達物質様薬剤 を微量注入して反射性排尿に及ぽす効果をみる化学的 刺激実験を行ったＬLCaへの化学的刺激では薬剤に
よって排尿閾值膀胼容量が減少して最大膀胱収縮圧が 上昇する排尿促進効果と, 排尿間值膀胱容量が増加し て最大膀胱収縮圧が下降する排尿抑制効果が記録され た。また，ノルアドレナリンと特にアセチルコリンに よる化学的刺激では反射性排尿が出現する前に無抑制 膀胱収縮様の小さな膀胱収縮が複数出現した。しかし, LSC とPo0への化学的刺激では排尿閾值膀胱容量が 変化しただけで,膀胱収縮圧には影響がなかった.ラッ 卜大脳皮質の部分切除脳では 1 側大脳皮質吻側 $1 / 30$ 内側部または外側部の除去で 1 週間後それぞれ排尿閾 值膀胱容量が増加または減少したが, 中央部または尾 側部 $1 / 3$ 皮質除去で排尿反射に明らかな影響はな かった.また, 皮質除去前後でいずれの除去群でも最 大膀胱収縮圧に差がなく, 残尿量もないか極めて少な かった. 2 週間後には部分除脳効果は減弱し部分除脳 前の排尿閾值膀胱容量に近付いた。

結論：橋以下の排尿関連神経機構が無障であれば膀 胱内圧測定上蓄尿期と排尿期の明確な排尿サイクルを 示し, 排尿反射は残尿なく遂行される。六コの橋排尿 中枢は LCa であり,この部位は排尿の開始と排尿の完 結の両方に関与している. LSC とPo0は蓄尿の維持に 働き, 排尿時には影響を及ほささない. 大脳皮質の排尿 にける機能は前頭部皮質における排尿開始時点の決定 にあるようで, 橋排尿関連部位と入出力関係にある皮 質の部分除脳効果が排尿閾值膀胱容量のみに現れたこ とは, 大脳皮質が橋排尿中枢のみならず橋の蓄尿に働 く部位とも強い連絡があることを推察させる。これら の結果は大脳皮質疾患に伴う多彩な臨床像と異なるこ とから種差が考えられるが, 化学的刺激実験から大脳 疾患に伴う排尿障害患者では橋の排尿関連部位への入 力のバランスが崩れて排尿障害を呈する可能性が考え られた。また, 脳幹以下の神経系の微細な障害の既往 または合併があれば，ょり上位の中枢神経系の障害で 脊髄の排尿関連部位への出力にアンバランスが生じて 排尿障害が出現する可能性も推察された.

大脳皮質および脳幹部疾患における排尿障害 : 山西 友典（千葉大）はじめに：大脳皮質, 脳幹部疾患に おける排尿障害を, 発生頻度と, 障害部位との関係に ついて検討した。

対象扔よび方法：無作為に選択した，大脳皮質梗塞 34 例, 単一皮質下小裔便塞55例, 脳幹部（橋中心）梗 塞30例における排尿症状の頻度を検討した。次に代表 的疾患として, 脳出血・梗塞122例, 脳腫崵28例, 正常 圧水頭症 (NPH) 24例, 脳炎後遺症10例, 晚発性小脳 